Canadian University Music Review

Canadian University Music Review

Revue de musique des universités canadiennes

\title{
How We Write Music Theory; How We Read It: A Dialogue with Harald Krebs's Fantasy Pieces
}

\section{Lynn Cavanagh}

Volume 22, numéro 2, 2002

URI : https://id.erudit.org/iderudit/1014503ar

DOI : https://doi.org/10.7202/1014503ar

Aller au sommaire du numéro

Éditeur(s)

Canadian University Music Society / Société de musique des universités canadiennes

ISSN

0710-0353 (imprimé)

2291-2436 (numérique)

Découvrir la revue

Citer ce document

Cavanagh, L. (2002). How We Write Music Theory; How We Read It: A Dialogue with Harald Krebs's Fantasy Pieces. Canadian University Music Review / Revue de musique des universités canadiennes, 22(2), 1-26.

https://doi.org/10.7202/1014503ar

All Rights Reserved @ Canadian University Music Society / Société de musique des universités canadiennes, 2003
Ce document est protégé par la loi sur le droit d'auteur. L'utilisation des services d’Érudit (y compris la reproduction) est assujettie à sa politique d'utilisation que vous pouvez consulter en ligne.

https://apropos.erudit.org/fr/usagers/politique-dutilisation/ 


\title{
COLLOQUY/DÉBAT: HOW WE WRITE MUSIC THEORY; HOW WE READ IT: A DIALOGUE WITH HARALD KREBS'S FANTASY PIECES
}

\author{
Lynn Cavanagh
}

He explained to her the various types of metrical dissonance and the labels associated with them, and the processes within which these metrical states can be employed. She listened raptly, delighted by the lucidity of his exposition and captivated by the material. ${ }^{1}$

Is this a manuscript about music or about mathematics? I am sick to death of these numbers and $X s$ and $Y s !^{2}$

Over the past two decades, concern has been expressed that the North American approach to thinking about music called "theory" has become self-referential and reductionist to the point of being little more than a scholarly equivalent of T. S. Elliott's "hollow men." To re-engage performers and historical musicologists in dialogue with them, theorists are advised to eschew structuralism, be wary of essentialism and, when not occupied with examining the way they apply analytic methodologies, engage in the multidisciplinary approaches needed to determine meaning in music. Whether with a sense of fervor or obligation, scholars engaged in work they call music theory have increasingly adopted the most consistently recommended tactics for its rehabilitation. ${ }^{3}$

Harald Krebs's Fantasy Pieces: Metrical Dissonance in the Music of Robert Schumann is both an extreme and an instructive case in point. Does music theory discourse tend to be dry? Krebs's book is a literary fantasy, set within Schumann's imagination and fictionalized private life, in the course of which

1 Harald Krebs, Fantasy Pieces: Metrical Dissonance in the Music of Robert Schumann (New York: Oxford University Press, 1999), 129.

2 Ibid., 43.

3The following authors propose or demonstrate a variety of solutions: Richard Cohn and Douglas Dempster, "Hierarchical Unity, Plural Unities," in Disciplining Music: Musicology and Its Canons, Katherine Bergeron and Philip V. Bohlman, eds. (Chicago: University of Chicago Press, 1992); Adam Krims, ed., with commentary by Henry Klumpenhouwer, Music/Ideology: Resisting the Aesthetic (Amsterdam: Gordon \& Breach, 1998); Patrick McCreless, "Rethinking Contemporary Music Theory," in Keeping the Score: Music, Disciplinarity, Culture, D. Schwarz et al., eds. (Charlottesville: University Press of Virginia, 1997), 48; Anthony Pople, ed., Theory, Analysis and Meaning in Music (Cambridge: Cambridge University Press, 1994); even Pieter van den Toom has said of theory, "[t]he rigor of its analytical disciplines need not be sacrificed, only the extreme isolation of that rigor," review-essay, "Will Stravinsky Survive Postmodernism?" Music Theory Spectrum 22 (2000): 106. 
Florestan and Eusebius read aloud and discuss a music theory manuscript of mysterious provenance. Do theorists give the impression that they codify abstract phenomenon for codification's own sake? The anonymous author of the theory manuscript makes it clear that metrical techniques are defined and labeled for the purpose of heightening aural perception of musical expressivity. Do analysts tend to concentrate on each musical work as a thing in itself? Here, analyses of individual works are linked with knowledge of Schumann's life and critical writings. Are some theoretical studies disappointingly narrow in scope? Although foremost a study of one musical parametre in the œuvre of one composer, Fantasy Pieces also demonstrates that its methodology has explanatory power for rhythmic expressivity in other tonal and non-tonal repertoire.

The present essay, like the book it discusses, contains both informal remarks and detailed description. In its first part, the essay engages with Fantasy Pieces as a source of consciousness-raising for how we read, write, and teach music theory. The second part of the essay presents for consideration criticism of two of Krebs's metaphors: metrical "narrative" and the "pathology" of metrical dissonance. The third part demonstrates an alternative approach toward meaning in Schumann's music: it develops Krebs's analysis of metrical processes in the first movement of Schumann's Symphony No. 3 into a hermeneutical reading by taking into account present-day understandings of Schumann's political and aesthetic beliefs.

As the dialogue portion of this essay opens, Florestan and Eusebius are busy discussing an analysis of their Papillon no. 1, which they have being reading together from the theory manuscript.

F.P.: Florestan argued, "Are accompaniment patterns of the 'oom-pah-pah' form, with thick chords on the 'pahs,' always metrically dissonant? I do not think so." Eusebius mused, "The author does admit that such a dissonance is very weak. And although it seems unconvincing at first to consider the accompaniment pattern at the opening of our Papillon dissonant, I have no difficulty hearing it that way within the context of our gradual intensification process." 4

Reader: I very much appreciate these interchanges between Florestan and Eusebius. First, I am reminded that, during the Renaissance, it was especially common for a technical treatise written for the edification of both experts and lay people to be couched entirely as friends discussing a topic of mutual interest. ${ }^{5}$ Reading a book that has interesting characters gathered in a relaxed setting is an appealing way of learning about the latest research in a field. Second, dialogic discourse is a solution to one of the greatest difficulties of writing music theory: airing the competing considerations that enter into a full argument. The questions, answers, and qualifying remarks that pass between Florestan and Eusebius as they read the theory manuscript have their practical

4 Krebs, Fantasy Pieces, 92.

5A famous, early seventeenth-century technical treatise couched as dialogue among friends is Galileo Galilei's Dialogues Concerning Two New Sciences, trans. Henry Crew and Alfonso de Salvio (New York: McGraw-Hill, 1963). 
as well as creative use. By reviving the dialogue format of certain ninth- to eighteenth-century instructive manuals on counterpoint (such as the Scolica enchiriadis, Morley's A Plaine and Easie Introduction to Practicall Musicke, and Fux's Gradus ad Parnassum), you anticipate a reader's reactions and questions, and thereby both clarify and strengthen your explanations.

F.P.: The following musical excerpts, drawn from the music of Robert Schumann, demonstrate the generation of interpretive layers by accentuation. In the left hand of example 2.1 [example 1 here], regularly recurring dynamic accents carve a 6-layer out of the sixteenth-note pulse (shown by the uppermost series of $6 \mathrm{~s}$ ). Registral (or contour) accents, created by the low points within the left-hand line, reinforce this 6-layer. Another 6-layer, coinciding with the dotted-quarter-note beats in example 2.1 (shown by the lower series of $6 \mathrm{~s}$ ), is created by durational accents (the longest note values in the right hand) and by new-event accents in the harmonic domain (i.e., by the harmonic rhythm). In example 2.2 , one 6-layer ( $1=8$ th) arises ...

Florestan said, "I am suddenly seized by an irresistible urge to order a slice of Torte." He beckoned to a waiter ... ${ }^{6}$
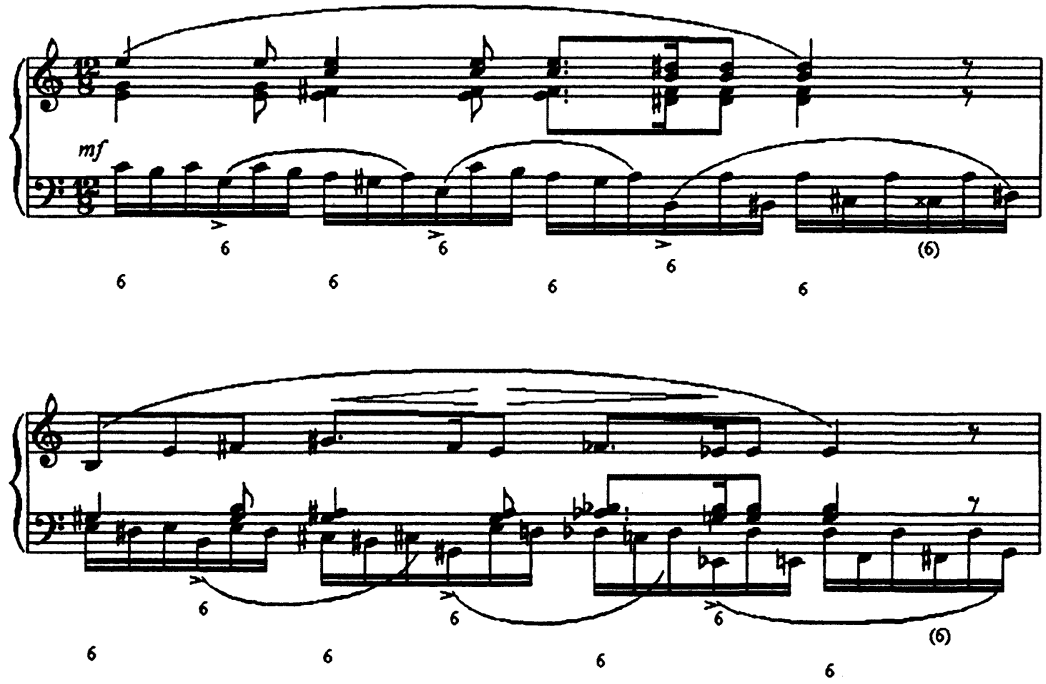

Example 1. Fantasy Pieces, example 2.1: a visual explanation of metrical dissonance occurring in Schumann's Intermezzo, op. 4 no. 4, bars 8-9. From Fantasy Pieces: Metrical Dissonance in the Music of Robert Schumann, by Harold Krebs. (C) 1999 by Harold Krebs and published by Oxford University Press, Inc.

Reader: I gather that Florestan does not necessarily have either a sweet tooth or a short concentration span. No one can read or listen to music theory discourse for very long at a time; it is meant to be digested in small amounts. This droll way of stating the dilemma is, moreover, in keeping with the tradition of including some humour in the technical discussion.

6 Krebs, Fantasy Pieces, 23-24. Throughout the present essay, block quotations from Fantasy Pieces in small type are from the theory manuscript (the book within a book), whereas quotations in regular type are from the narrative and dialogues. 
F.P.: [Eusebius said,] "The labels for the displacement dissonances that we have constructed would be $\mathrm{D} 2+1$ and $\mathrm{D} 3+2$, respectively, or, if the musical context justified a backward hearing D2-1 and D3-1." Florestan said with some asperity, "I am growing tired of all of these numbers. Must every metrical state be labeled with numbers? Is metrical conflict only a matter of measurement and counting?" Eusebius calmly replied, "Whereas I, too, am not overly fond of numerical labels, I must admit that the author's labels nicely encapsulate some of the properties of the various metrical states. And perhaps the usefulness of the numerical labeling system will become clear later on in the manuscript." Florestan grunted and said, "Let us hope so."7

Reader: You let Florestan speak for those who have had the experience of theory courses (and theory textbooks) that take as their final goal teaching a system of naming, numbering, and labeling the abstract qualities of aural phenomenon. ${ }^{8}$

Other students of theory were more fortunate: in their courses the labels and numbers were learned and subordinated, to become the unconscious language for talking about insights into music. Like Eusebius, they know, when presented with a new methodology and its labeling system, that it is meant as a means to a musical end.

From studying Fantasy Pieces I now understand that a "displacement dissonance" is a metrical incongruity in which conflicting metrical groups from different textural layers contain the same number of pulses but occur with their strong pulses unaligned: for example, groups of two pulses shifted forward by one pulse in one or more different layers, which you represent by D2+1. I gather that a "grouping dissonance" is a metrical incongruity in which metrical groups of differing numbers of equal-length pulses occur in close proximity (vertically or horizontally): in G3/2, for example, groups of three pulses and groups of two pulses oppose each other.

Certainly you and I agree with Florestan that " $D 2+1$ " is not the sort of "representation" of a musical passage that a performer mentally rehearses or a listener recalls afterward. Nor is a mere system of definitions something that inspires me to want to teach and write about metre in tonal music. But numerical labels for precisely defined states appeal to the need for a descriptive language that supports discussion of metrical techniques without confusion or ambiguity. Your speculation that even a nineteenth-century composer would appreciate this precision does not seem far-fetched. Of course, we all must go to some effort to learn the categories and definitions.

F.P.: Florestan asked a passing waiter to bring some coffee beans. When the puzzled waiter had laid a handful of beans on the table, Florestan said to the equally puzzled Eusebius, "I though we might find it easier to understand the author's descriptions if we constructed some little models. Why don't you build a coffee-bean model of the dissonance G3/2 while I build G5/3?" ... After studying each other's models, they read on. ${ }^{9}$

7 Ibid., 36.

8This dilemma was expressed most convincingly by John Buccheri during the College Music Society Workshop "Sparking Aural Imagaination II" (University of Oklahoma, June 2000).

9Krebs, Fantasy Pieces, 31. The coffee bean illustrations represent metrical hierarchies in the 
Reader: Florestan, who previously was disdainful of the abstract, numerical symbols for metrical incongruities, is busy translating them into a visual symbol of the intended aural effects. Each of us approaches a subject from a slightly different knowledge base and each of us learns through different means; therefore, to a greater or lesser extent, one must rely on oneself to make sense of written discourse. As modeled here by Florestan and Eusebius, every once in a while a reader is obliged to put down the book and construct or rehearse one's own mental, or possibly physical, image of what is being described. I made sure that I added, to Florestan's and Eusebius's visual representations, aural images of the sounds of different instances of grouping dissonance and displacement dissonance. Later in your book, Clara Schumann's rapt attention while Robert explains the theory of metrical dissonance may seem at first like a theorist's fantasy, but if Clara attends actively to what Robert says and controls the pace of presentation, it is entirely possible. We can imagine them singing to illustrate a point, going to the pianoforte where each plays a passage in different ways to better hear the interaction of metrical layers, and improvising different ways in which the music might have been composed. Your characters demonstrate to us that appreciation of music theory discourse is dependent upon a very active reader, mentally and physically.

Each paragraph of rigorously framed definitions and close analytic detail takes a chunk of time to digest. Although more time is needed to absorb the meaning of such passages than the same number of words in other books requires, the compensating realization is that it never takes a reader as long to grasp a clearer notion of the metrical technique in the music under discussion as it would have taken you to devise and illustrate your methodology. Your portrayals of Florestan and Eusebius demonstrate the effort that a reader is meant to bring to the dialogue of scholarship in music theory. It is the same effort any student must bring to learning a new subject.

F.P.: Florestan sipped some brandy, then continued, "My discussion of the Caprices reminds me of another significant influence on my rhythmic style: Paganini could, of course, never have written these works [the Caprices] had he not learned the art of writing for solo violin from Johann Sebastian Bach. I, too, learned a great deal from old Bach, including some aspects of the treatment of metrical conflict. I became very familiar with the master's keyboard works in the early $1830 \mathrm{~s}$, at which time I was not only playing but also assiduously analyzing them."10

Reader: It seems logical that Schumann's capacity to teach himself is responsible for his knowledge of metrical devices in other composers' music. Compositional pedagogy has continued to pay scant attention to principles of rhythmic organization in favour of principles of pitch organization. " An examination of

\footnotetext{
manner of dot structures in Fred Lerdahl and Ray Jackendoff's A Generative Theory of Tonal Music (Cambridge, Mass.: MIT Press, 1983).

10 Krebs, Fantasy Pieces, 70-71.

$11 \mathrm{~A}$ large part of the reason for this omission is historical. The ancient agenda of music theory arose from Medieval musical traditions (heavily influenced by classical Greek theoria), whose composers
} 
even the most recent textbooks in use shows that rhythmic techniques, even those that are nameable in broad categories, are only beginning to be the subject of students' analysis and writing activities. ${ }^{12}$ The increased attention in the professional literature to analyzing rhythmic techniques in terms of compositional strategies and expressive aims has not been equaled in theory pedagogy. ${ }^{13}$ When we can explain metrical dissonance to our undergraduate students, we will truly understand it.

F.P.: ... The B section of the Mazurka op. 17 no. $1 \ldots$ In mm. 41-50 and 53-58 the left hand consists of an "oom-pah" pattern that forms a 2-layer dissonant against the right-hand melody (in which a 3-layer is formed by varied repetition of a rhythmic pattern). As the phrase ends approach (bars 52 and 60), Chopin expands the left hand's "oom-pah" pattern to "oom-pah-pah," thus creating the potential for resolution into the primary consonance [example 2]. At the first phrase ending, however (bars 51-52 ... ), the right hand refuses to collaborate in the resolution; instead of continuing its 3-layer, it lapses into repetition of the rhythm "quarter-eighth-eighth," thus taking over the 2-layer previously articulated in the left hand. This "layer exchange" subverts metrical resolution at this phrase ending. At the next phrase boundary, on the other hand (bars $59-60 \ldots$ ), the right hand does maintain its 3-layer and joins the left hand in a definitive metrical resolution. The earlier evasion of metrical resolution makes the resolution at the end of the $B$ section all the more satisfying. ${ }^{14}$

Reader: This is a good example for illustrating the relevance of metrical analysis to first-year undergraduate study of the materials and techniques of tonal music. Student analysis of the passages from a Chopin mazurka shown in example 2 would routinely attend to the motivic construction of the melody, harmonic conflict between inner parts and pedal point, effects of nonharmonic tones, and the pedal point's mimetic role. But students could also listen to and

were concerned with the need to convey the contemporaneous method of treating pitch consonance and dissonance to the next generation of composers. On the other hand, during much of the Medieval era there was no need to advise students on the use of "consonant" and "dissonant" metrical states in appropriate relationships because the metric modes of prose, poetry, and dance, and other conventions of worship, drama, and dance naturally organized musical time into variegated metric states (cf. Schumann, as reminded by Berlioz's music, on the "unfettered discourse and higher poetic punctuation of Greek choruses, the Bible, and Jean Paul's prose," quoted in Krebs, Fantasy Pieces, 12). Because "metrical consonance" and "dissonance" were not one of the traditional problems that music theory had set for itself, later, with the rise of purely instrumental music and its growing emancipation from dance models, composer-theorists had no precedent for discussing metrical states in their theory treatises. When in the nineteenth century analytical commentary on music undertaken apart from composition pedagogy emerged, it, too, had no models for discussing rhythmic organization.

12Robert Gauldin's Workbook for Harmonic Practice in Tonal Music is noteable. The unit on diatonic harmony contains one chapter, coordinated with a chapter in the textbook, of exercises in composing and identifying instances of "Rhythmic Deviations and Metrical Dissonance" (New York: W. W. Norton, 1997), 41-44.

13 In addition to books and articles on aspects of thythm in the Bibliography in Fantasy Pieces, see also Joseph P. Swain, "Dimensions of Harmonic Rhythm," Music Theory Spectrum 20 (1998): 48-71; Channan Willner, "Stress and Counterstress: Accentual Conflict and Reconciliation in J. S. Bach's Instrumental Works," Music Theory Spectrum 20 (1998): 280-304; Eytan Agmon, "Musical Durations as Mathematical Intervals: Some Implications for the Theory and Analysis of Rhythm," Music Analysis 16, no. 1 (1997): 45-76; Roger Kamien, "Conflicting Metrical Patterns in Accompaniment and Melody in Works by Mozart and Beethoven: A Preliminary Study," Journal of Music Theory 37, no. 2 (1993): 311-48; David Smyth, "Patterning Beyond Hypermeter," College Music Symposium 32 (1992): 79-98; John Roeder, "Pitch and Rhythmic Dramaturgy" in Verdi's 'Lux Aeterma'," $19^{\text {th }}$ Century Music 14, no. 2 (1990): 169-85.

14 Krebs, Fantasy Pieces, 202. 

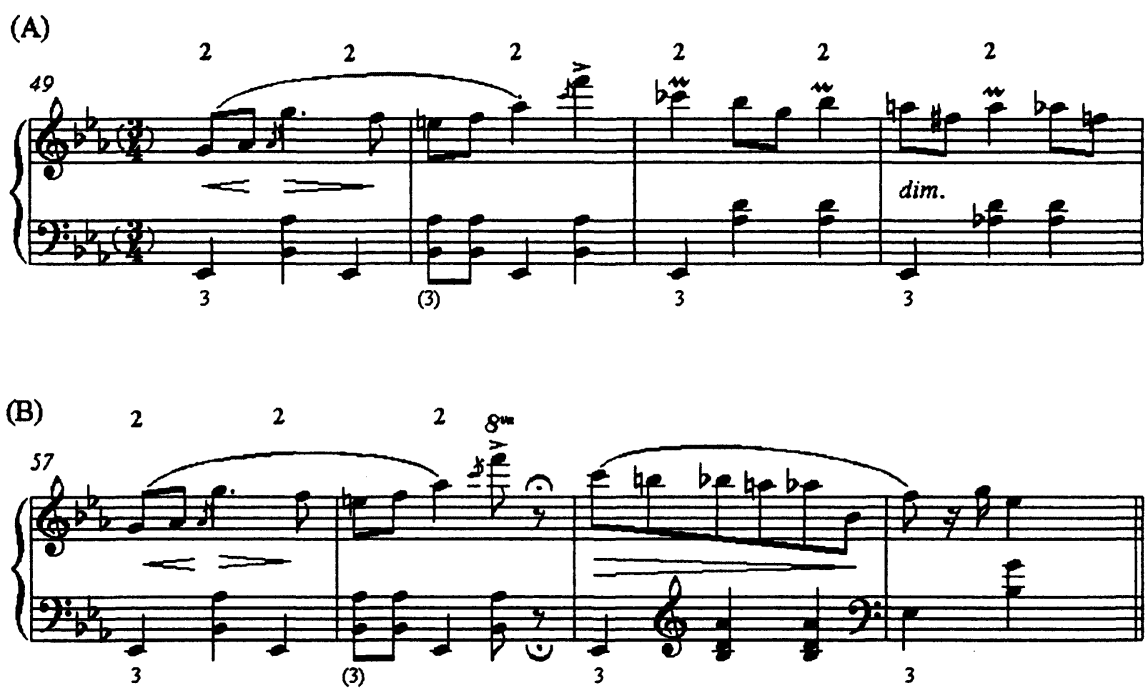

Example 2. Fantasy Pieces, example 8.15: a visual explanation of (A) grouping dissonance, and (B) its eventual resolution, occurring in Chopin's Mazurka op. 17 no. 1, bars 49-52 and bars 57-60. From Fantasy Pieces: Metrical Dissonance in the Music of Robert Schumann, by Harold Krebs. (C) 1999 by Harold Krebs and published by Oxford University Press, Inc.

analyze the layering and alternation of duple and triple metres caused by motivic and registral factors. The difference in cadential effect between these two passages, then, would not be attributed solely to dominant harmony in bar 52 compared to tonic harmony in bar 60 but-as is the true situation-also to metrical dissonance in bar 52 resolved by metrical consonance in bar 60 . Moreover, when the pitch domain is not habitually isolated from the rhythmic, the power of music analysis is apt to be more readily appreciated by undergraduate students. ${ }^{15}$

It is possible, however, that the rhythmic organization of tonal music will never be reduced to chapters and exercises in textbooks as easily as pitch organization in tonal music has. It may behoove all who want to be able to analyze and talk about rhythmic organization, in meaningful ways and with a common vocabulary, to absorb the results of current scholarship in rhythm and metre from the professional literature. But this is not an easy task.

F.P.: Eusebius continued, "There are plenty of additional examples of coordination between phrase ends and metrical resolution in our works. In the finale of the Sonata op. 11, the first theme ... is permeated by subliminal G3/2 ( $1=$ quarter), but temporary resolutions of the metrical dissonance occur at the

15Rhythm and pitch, although of primary importance in many types of Western music, are, of course, not the only musical parametres. In the reader's experience, students new to music analysis are more receptive to technical discussion of music when their attention is drawn to process in a number of correlated (or uncorrelated) musical parametres than they are when process is traced in only one parametre, whether rhythm or pitch. 
two main cadences of the theme (at $\mathrm{mm} .8$ and 16). In the first movement of the First String Quartet, we associate important cadences at the end of the exposition ... and the recapitulation ... with resolution of D6+3 (1=8th) ..."16

Reader: Your Schumannesque interlocutors know, from memory, the piece that you were using as an example; therefore, they immediately understand what you are getting at in your presentation of the example and your explanation of a compositional technique within it. Then, to reinforce this understanding, they call to mind other snatches of music that contain the same rhythmic effect as the one just described, which they can do because they know similar pieces. Admittedly, in recollection of specific works, Florestan and Eusebius have an advantage over anyone else reading the theory manuscript - an advantage that has been exaggerated (not every composer will have such a vivid memory of individual movements dating back to all stages of the composer's career). ${ }^{17}$ This fictional extravagance points up an important aspect of reading music analysis: one can only comprehend another's analysis of a piece if one's aural imagination contains a prior, linear impression of the work, both at its surface level and at pertinent large-scale levels. Only this foreknowledge can make it possible for a reader of a music theory work such as Fantasy Pieces to follow analyses of musical events occurring on many levels. ${ }^{18}$ Florestan and Eusebius do not tire quickly from the detail of your longer explanations because, rather than correlating them with the notation of scores, or with excerpts reproduced in the manuscript, they can compare them with their aural recollections of the rhythmic events to which you refer. They can do this because their memories are prepared to begin a mental performance of the piece from various starting points. ${ }^{19}$ Logically, even some measure numbers are comprehensible to them if they recall the large framework as containing a certain number of sets of regular (and irregular) hypermetric units.

F.P.: The reader is urged to consult scores of the works analyzed here. It was not possible to include all excerpts mentioned, and some excerpts are presented only in simplified form. ${ }^{20}$

Reader: Naturally, when measure numbers are used in the course of a comprehensive analysis of a lengthy movement, most of these refer to neither readers' aural recollections nor printed excerpts, but to a score. Although

16Krebs, Fantasy Pieces, 145.

17 In the chapter "Carnaval des analyses," Eusebius and Florestan also keep track of analytic detail concerning "Un bal" from Berlioz's Symphonie fantastique (187), various works by Chopin (199), one by Clara Schumann (209), and Brahms's Piano Sonata, op. 5, I (219), all of which Schumann can be expected to have known.

18Similarly, an analytic interpretation of a novel is otiose until one has read the novel and become familiar with its characters, outstanding motifs, and the sequence of events. Then one may read an essay about it, comparing the commentary with one's own conception of the large plan of the novel and the place therein of details and quoted passages. The situation of music analysis is more extreme because music measures time more precisely than does literature, and because its events are much more abstract. Therefore, analytic commentary on music can usually only be evaluated if the reader compares it with what is known to be the precise configuration of events and relationships in time. By way of compensation, music is easier than prose to commit to memory.

19The phrase "mental performance" is an adaptation of John Buccheri's pedagogical notion of "mental rehearsal," as described in his presentation "Sparking Aural Imagination II."

20 Krebs, Fantasy Pieces, 271 n. 1 (chap. 8). 
necessary, your advice here to consult scores may mislead some readers to expect that one can learn to appreciate metrical techniques more fully in any of these works by having merely heard a performance and reading the analysis in consultation with the score. Under these circumstances alone, however, music-analytic commentary quickly disappoints. First, it is very tiresome continually to check and recheck the score in order to make sense of the author's remarks. Second, even having a passing knowledge of how the work goes, and having checked and rechecked the score during reading of an analysis, too much effort will be made contextualizing the author's individual observations to evaluate and appreciate the overall point. I have only truly appreciated your analyses of works that I already knew or have made a point of learning thoroughly.

I have wondered, though: if analysis pedagogy is still largely pitch-dominated, is it not because tonal theory has made it possible for us to understand a piece of music as a whole-that is to say, as more than a series of local events? Surely metrical dissonances are purely local in significance, characterizing a theme, heightening forward drive at transitional points, and emphasizing significant cadences?

F.P.: Most musical works are, in fact, spanned by a succession of metrical consonances and dissonances-a "metrical progression." ... Possible progressions of this type are large neighboring motions of the form "C-D-C" (where the work beings in a primarily consonant fashion, becomes more dissonant, and ends with restoration of the original mainly consonant state) ... ( ... a state " $D$," composed of a variety of individual dissonances or a variety of degrees of intensity of a single dissonance). Such informal "bird's-eye views" of a metrical progression take us to the rhythmic heart of a given work-to its most basic metrical "narrative." $2 \mathrm{I}$

Reader: I infer from the quotation marks that the word "narrative" is used in a figurative sense. Although you never explain your adoption of this metaphor, I have concluded that before doing so you grappled with the troublesome lack of an unbiased term (technical or nontechnical) for summarizing what happens over the course of a piece of music: "structure," "design," and "shape" all imply a synchronic totality; "process" is mechanistic in connotation; "narrative" has the advantage of being both diachronic and creative in connotation. After the introduction of the phrase, all of your analyses of entire movements begin with mention of what you matter-of-factly call the "basic metrical narrative" of the piece, including "preparation of two main dissonances in the introduction followed by their development"; "a variant of 'D-C-D" "; "constant struggle between 6- and 4-layers"; "no single narrative, but many interesting subplots"; and many other, less succinct summaries of the course of metrical events. Consciously or unconsciously, you have chosen a metaphor that allows for the fact that metrical states succeed each other in time, not space, that they are necessarily compelled neither toward symmetry nor toward closure (although they may be teleological), and that the succession of metrical states and events always serves contextual purposes. ${ }^{22}$ Their presentations, foreshadowings,

21 Ibid., 82, 84-85.

22 "I investigate ... the roles of metrical conflicts within their actual contexts ...", Krebs, Fantasy Pieces, 21. 
foregroundings, new combinations, transformations, and partial or total resolutions or nonresolutions are "told" in the course of an either linear or apparently nonlinear disposition. ${ }^{23}$

You include among the summaries of basic metrical narratives many that do not constitute an overarching, single totality. Perhaps the foremost reason why you settled on the "narrative" rather than the "structure" metaphor (as in "tonal structure") is that you do not want to give the impression that metre in the large context can generally be described with one of just a few paradigms for a single, overarching totality.

Yet I have reservations concerning the metaphor. As there is a substantial body of secondary literature on narrative theory as it applies (or does not apply) to music, it seems inappropriate that you neither cite nor explicitly disassociate yourself from this literature. Murray Dineen has pointed out that we are not very self-conscious about the assumptions behind the vocabulary we use to speak of music. ${ }^{24}$ Built into your use of the term "narrative" is the assumption that there is no necessary distinction between story-telling techniques, or narratography (foreshadowings, transformations, recombinations, resolutions, and the like), which are applicable to music compositional events, and actual story-telling, or narrative, which is virtually impossible to achieve in instrumental music. ${ }^{25}$ As Stephen McClatchie has argued, narrative theory has important observations to make about meaning in vocal music and program music; therefore "[i]f all music is understood as narrative, its use quickly becomes banal, capable only of tautologously cloaking old viewpoints with trendy new clothing."26 Perhaps the reader of Fantasy Pieces is meant to assume that your use of the term is doubly figurative: "narrative" is meant to evoke a part of itself-narratographywhich, in turn, is meant to evoke the idea that music-compositional techniques may be like methods of story-telling. At first I thought that your use of the word "narrative" to describe metrical processes would be connected with Schumann's belief that music should be biographically suggestive ${ }^{27}$ - that the best music

$23 \mathrm{~A}$ precedent for a metaphor from the language arts refering to the role of metrical dissonance is Richard Cohn's metrical analysis of a Beethoven scherzo in which he accounts for what he calls its "dramatic" element; see Richard Cohn, "The Dramatization of Hypermetric Conflicts in the Scherzo of Beethoven's Ninth Symphony," 19 Century Music 15, no. 3 (1992): 188-206. But there is a crucial difference between the two literary genres. Drama uses the present tense and, like music, is meant to give a sensation of unfolding in present time. Narrative, typically written in past tense, concerns events that happened prior to the time of narration-a temporal distinction difficult to convey in music.

24"Allegory is the tacit subtext of analysis, so tacit yet so ubiquitous as to constitute the prime ideological motivation of much that passes as music theory-to masquerade scholarly fictions about the way music works as fact." Murray Dineen, review of Alan Street's article "Superior Myths, Dogmatic Allegories: The Resistance to Musical Unity," in Canadian University Music Review 20/2 (2000): 95.

25Lawrence Kramer, Classical Music and Postmodern Knowledge (Berkeley and Los Angeles: University of California Press, 1995), 99-100.

26Stephen McClatchie, "Narrative Theory and Music; Or, the Tale of Kundry's Tale," Canadian University Music Review, 18/1 (1997): 17.

27 John Daverio, Robert Schumann: Herald of a "New Poetic Age" (New York: Oxford University Press, 1997), 10-11; Leon B. Plantinga, Schumann as Critic (New Haven: Yale University Press, 1967), 122. It was during the editing of this colloquy feature that we received the news of John Daverio's untimely and tragic passing. Schumann research, and musicology in general, has lost one of its most impassioned and informed voices.-ED. 
alludes to other artistic media and, ultimately, to life. ${ }^{28}$ Is it possible to demonstrate that metrical dissonance in a musical work has specific extramusical meaning?

F.P.: [Eusebius] looked ahead to the next section and said, "Ah, Florestan, here comes an analysis of one of your finest recent movements," and began to read.

"Florestan" (Robert Schumann, Symphony No. 3, Op. 97, First Movement)

Summary

1. Main recurring dissonances: $\mathrm{G} 6 / 4, \mathrm{D} 6+4(1=8 \mathrm{th})$.

...

6. Frequency of change of metrical state: varies from section to section (e.g., increasingly frequent during the first theme, infrequent during the second theme).

7. Basic metrical narrative: constant struggle between 6-and 4-layers, the former, and metrical consonance, ultimately being victorious. Subplot: intensification of D6+4. ${ }^{29}$

F.P.: The rate of metrical change in the second theme is much slower than in the preceding sections; individual metrical states last much longer than before. This increased metrical stability lends most of the section an Eusebian quality, in strong contrast to the Florestanian character of the surrounding music. ${ }^{30}$

Reader: You mean that metrical dissonance and metrical consonance are expressive in the same manner as other binary oppositions in Schumann's music - vivace and lento, forte and piano, mit Humor and innig - the two sides of his personality. Can the meaning of metrical dissonance be more specific?

F.P.: [In his vocal music] Schumann employs metrical dissonance more frequently in connection with negative states. ${ }^{31}$

F.P.: If Schumann related these poems ["Es leuchtet meine Liebe," "Die Löwenbraut"] to the conflicts within his own life, then the fact that he prominently or pervasively employed metrical dissonance when setting them suggests that he consciously or subconsciously linked that device with his personal conflicts. It is not farfetched to assume that in Schumann's instrumental music, too, metrical dissonances frequently represent the conflicts that he was working through in his life ... and their resolutions as expressing a desire to come to terms with conflict. ${ }^{32}$

Reader: Consistent with this hypothesis, you suggest that the particularly powerful and prolonged metrical dissonance of the first movement of Faschingsschwank aus Wien, op. 26, composed (or at least begun) during a sojourn in Vienna, are a musical expression of Schumann's anger and protest against the narrow-mindedness of the rulers of Viennese cultural life. ${ }^{33}$ Perhaps, though, the relationship between metrical dissonance in this movement and Viennese culture as Schumann observed it is more subtle than representation of Schumann's personal attitude. According to the title, the four movements can be thought of as constituting a mocking tale (Schwank) set during carnival time

28Leon Botstein, "History, Rhetoric, and the Self: Robert Schumann and Music Making in German-Speaking Europe, 1800-1860," in Schumann and His World, ed. R. Larry Todd (Princeton: Princeton University Press, 1994), 26.

29 Krebs, Fantasy Pieces, 236-37.

30 Ibid., 240.

31 Ibid., 161.

32Ibid., 171-72.

33 Ibid., 216-19. 
time (Fasching), therefore portraying tipsy revelers, costumed pranksters, and masked dancers (some of whom are likely to have disguised their social class for the purpose of social intrigue and one-upmanship) ${ }^{34}$ In Schumann's musical tale, these images are portrayed with the help of musical irony, including metrical disruptions within waltz metre. The irony, on one level, is mocking commentary on Fasching, but on a deeper level may also be thought of as Schumann's sardonic commentary on the petty politics of Viennese cultural life. In short, there is likely more to the extra-musical aspect of metrical dissonance in this movement than that its creation was a form of therapy for Schumann's thwarted Viennese ambitions.

F.P.: [Eusebius, to Florestan] What comical effects, what breathless excitement you have communicated, for example, by the pages of syncopation in Carnaval and the Davidsbündlertänze! ${ }^{35}$

Reader: Syncopation, you would probably agree, is better classed as a type of "rhythmic deviation," 36 because it depends for its effect upon strict retention of the existing metre. Many of Schumann's instrumental works that have descriptive titles cast doubt on the notion that metrical dissonance was predominantly a way of expressing conflict or negativity. Examples include the exuberant regroupings of "Aufschwung" and the scherzando displacements of passages in "Fabel," both from the Phantasiestücke, op. 12 of 1837 (composed shortly after Schumann emerged from a bout of depression). Passages of metrical dissonance that you describe include the serene middle section of "Vogel als Prophet," the solemnity of "Eintritt," both from Waldscenen, and the whimsy of "Grillen" from the Phantasiestücke, op. 12.37

F.P.: Eusebius smiled, then went on, "I have occasionally employed metrical dissonance in a manner that suggests neither conflict, panic, nor comedy, but rather evokes a suspended, dreamlike, hovering state. Do you recall the little 'Impromptu' that I dashed off in 1838, and that we recently included in our Albumblätter op. $124 \ldots$...? In this piece I superimposed three layers of motion, none of which possesses obvious primacy ... It is difficult for listeners to come to a convincing metrical interpretation for this piece; they will likely find themselves hovering deliciously and dreamily between meters." Florestan nodded and added, "These dreamlike pieces of yours perhaps come closer to liberating music from the 'tyranny of metre' than my more violent and impassioned dissonant passages." 38

Reader: Other than in this one paragraph, an explicit connection between a particular instance of metrical dissonance and a positive mental stateSchumann's flights from reality, his personal times of contentment, romance, or freedom from care-is rarely made in Fantasy Pieces.

34 The author is grateful for advice concerning Fasching given by a reviewer of this essay.

35 Krebs, Fantasy Pieces, 4.

36Gauldin, Workbook for Harmonic Practice in Tonal Music, 117-20.

37 Krebs, Fantasy Pieces, 94, 55, 49.

38 Ibid., 172-73. 
F.P.: In this book I investigate the pathology of musical metre-the manifold disruptive and distortive conditions that affect what we generally call "the metre" of a musical work. ${ }^{39}$

F.P.: Eusebius haltingly continued ... What better means to represent ill health-a mind gone awry-than metrical dissonance? Insanity is a theme that has recurred in our lives and in our music. ${ }^{40}$

Reader: Unlike Dieter Schnebel, whom you cite in the music theory manuscript, you do not attempt to explain metrical dissonances in Schumann's music as evidence of mental deterioration. ${ }^{41}$ Nevertheless, a link between illness and metrical dissonance is suggested in your preface by the word "pathology." The notion that Schumann may have sometimes used metrical dissonance as a symbol of mental illness is a recurring idea in the music theory manuscript and in the Florestan-Eusebius dialogues.

There is reason to believe that as a young man Schumann may have found appeal in simulating or symbolizing moods of insanity or schizophrenia in his music:

... when he grew up, the viewpoint prevailed that genius and madness are inseparable. Many artists of the romantic era confidently engaged in "mad" behavior-debauchery, drinking, drug use, irrational thinking-hoping thus to stimulate their creativity. When Schumann was younger and unmarried he tried to do some of this too [particularly the drinking], despite his fear of losing self-control and committing suicide ... [as had a sister and one other family member]. ${ }^{42}$

By the time he was in his mid-thirties, Schumann was aware of new scientific thinking that viewed mad, eccentric behaviour as illness rather than possession by spirits, creative or otherwise. ${ }^{43}$ Meanwhile, his own severe and recurring depressive episodes strengthened his fear of insanity. Given this fear, the continued pervasiveness of metrical disruption in his music would more logically have been an attempt to release or condition his fear of madness than a desire to symbolize madness.

As your fanciful narrative and dialogues are meant to have taken place when the composer's auvre was virtually complete, that is, toward the end of his life, you decided to incorporate descriptions of symptoms of his illness during that time.

F.P.: [Florestan] “... The two complementary sections [of the second movement of the Piano Quartet in C minor] combine to form a movement in which

39 Ibid., vii.

40 Ibid., 173.

41 Dieter Schnebel, "Rückungen-Ver-rückungen: Psychoanalytische und musikanalytische Betrachtungen zu Schumanns Leben und Werk," in Musik-Konzepte, Sonderband Robert Schumann I, Heinz-Klaus Metzger and Rainer Riehn, eds. (Munich: edition text + kritik, Nov. 1981): 4-89, cited in Krebs, Fantasy Pieces, 20.

42 Peter Ostwald, Schumann: The Inner Voices of a Musical Genius (Boston: Northeastem University Press, 1985), 191.

43 Ibid., 192. 
metrical consonance and dissonance are used, I believe, quite boldly and effectively."

When he had finished, Florestan thirstily drained his glass. As he did so, his gaze happened once more to fall upon the mirror across the room. He gasped in terror when again he saw the gaunt violinist, providing demonic music for a crowd of dancing skeletons and wraiths. But now the wraiths had the faces of Hummel, Moscheles, Bach, Beethoven, and Schubert; and now he heard the sounds of the violin-the ferocious displacements from the ending of Paganini's sixteenth Caprice. Before Raro was able to stop him, he hurled his glass at the mirror ... Clara ... burst into the room. She stared aghast, at the broken mirror and at Robert's wild-eyed and terrified face. It took her some time to calm him and to convince him that it was time to go to bed. With great effort-for in reaction to his outburst, he soon went limp as a ragdoll-she succeeded in transporting him to his room and putting him to bed. ${ }^{44}$

Reader: This scene, because it draws from an actual incident, indirectly develops the notion that mental illness found expression in Schumann's music. It also risks giving the impression of a relationship between Schumann's creative work and his premature death. Presumably in a mood of both whimsy and lucidity, Schumann has spent a pleasant evening imagining Florestan, Eusebius, and Raro reminiscing about some of the composers that inspired his approach to metrical dissonance, among them the technical wizard Paganini. Many years earlier, Schumann happened to see a grotesque caricature by Johann Peter Lyser of Paganini surrounded by ghosts and dancing skeletons. ${ }^{45}$ The intended horror of the drawing captured his imagination, with the result that, while working on a piano arrangement of Paganini's G-minor Caprice two days later, his visual imagination became involuntarily occupied by an animated version of the caricature. He wrote in his diary, "the picture often hovered before me, and I think that the close [of the arrangement] reflects it." 46 The stimulation of his mental work on Paganini's music produced and sustained a mental, visual impression (by means of the mental faculty known as synaesthesia, perhaps), to the advantage of the expressivity of his piano arrangement. ${ }^{47}$ Although at the

44 Krebs, Fantasy Pieces, 80-81.

45 Peter Ostwald, Schumann: The Inner Voices, 91.

46Translated in Daverio, Herald of a "New Poetic Age," 94, from Schumann's Tagebücher, Band I: 1827-1838, Georg Eisman, ed. (Leipzig: VEB Deutscher Verlag für Musik, 1971), 4 June 1832.

47 Schumann's heightened sensitivity to sensory stimuli, his Florestanian impulsiveness when an idea fired his imagination, and his Eusebian taciturnity in social situations are typical of a personality type that has been identified by the American psychologist Elaine Aron. It is a normal and genetically determined personality type occurring in 15 to 20 percent of any human population, whose traits, as well as resulting directly or indirectly from heightened sensitivity to all manner of sensory stimuli, are frequently evidenced by maladaptation to the rigors of modern, Western society (and therefore socially stigmatized in the Western world), but also evidenced by the (more universally approved) trait of perceptual sensitivity to art and spirituality. Aron hypothesizes that the evolutionary success of humanity may have been dependent upon the existence of this small proportion of the population, necessary to fulfill a priestly and advisory role to counterbalance the relatively aggressive, expansionist aspirations of the majority. Elaine N. Aron, The Highly Sensitive Person (New York: Broadway Books, 1996), 3-18; Elaine N. Aron and Arthur Aron, "Sensory-Processing Sensitivity and Its Relation to Introversion and Emotionality," Journal of Personality and Social Psychology, 73 (1997): 345-68. 
time he recorded this incident in his diary he was extremely anxious about his career, he was not mentally ill. ${ }^{48}$ On the other hand, during the period in which Fantasy Pieces is set, Schumann may have been afflicted with neurological decay of the type symptomatic of the advanced stage of syphilis, which he may have contracted in 1831 - as Daverio believes the surviving medical evidence best indicates ${ }^{49}$-or his illness may have been psychiatric, a "major affective disorder"- as biographer Ostwald has contended. ${ }^{50}$

The fictional evening in Fantasy Pieces quoted above melds together Schumann's mental faculty that enhanced the vivid poeticism of his music and his behaviour when insane. It blurs the distinction between Schumann's sensitive, poetic imagination when he was healthy, and his mind when incapacitated, as if the two belong along the same continuum. It thereby reinforces the nineteenth-century romantic belief in a link between genius and madness. Schumann's artistic sensibilities and his inordinate sensitivity to the stresses of making a career were innate to his personality. Stress, and resulting severe depression, were exacerbated by career decisions such as accepting the post of music director in Düsseldorf. But the romantic notion that insanity followed inevitably from his artistic sensibilities needs to be laid to rest. ${ }^{51}$ The metrical freedom of Schumann's music finds its most satisfactory explanation not in a context of recurring premonitions of a horrible death, but in his capacities for creative strength and lucidity.

With the intention of adjusting the balance between negative and positive states of mind as explanation for Schumann's interest in metrical dissonance, the remainder of this essay aims to demonstrate that a worthwhile context in which to understand Schumann's compositional choices, among them use of metrical dissonance, are his beliefs concerning music as an art form and music's role in society. This will necessitate an outline of the social and ideological context, explanation of a hermeneutic method that is applicable to the case of Schumann's music, and an example from his works, to be aided by the analysis in Fantasy Pieces of the first movement of Schumann's Symphony No. 3.52

According to Leon Botstein, Schumann was a rare case in the history of the relationship between music and ideas: although his strongest schooling was in philosophy and literature, as a young man Schumann chose music as his career not for music's sake but because both philosophy and literature had failed to

48Ostwald, Schumann: The Inner Voices, 90-91.

49Daverio, Herald of a "New Poetic Age," 484-85. The diagnosis of syphilis in its final stage (progressive paralysis) is based on Daverio's interpretation of available portions of the diary maintained by the attending physician in the asylum, which had only recently become accessible.

500 stwald did not have access to the attending physician's records of Schumann's asylum care (Ostwald, Schumann: The Inner Voices, 277); moreover, he discredits circumstantial evidence that as a young man Schumann showed early symptoms of syphilis (ibid., 75, 268-69). Ostwald diagnoses the cause of death as suicide by means of self-starvation (ibid., xii, 293).

51 On the continuing misunderstanding perpetuated by the myth of the sensitive artist necessarily prone to mental illness and suicide, see Aron, The Highly Sensitive Person, 124-26.

52Krebs, Fantasy Pieces, 236-43. 
lead to the humanistically oriented divine truth that he sought. He became a composer and music critic because he had reason to believe that neither religion nor philosophy, but instead art, and only music among the arts, could express what he once called "the very image of life." 53

Schumann's artistic ideology cannot be separated from the turmoil of mid-nineteenth-century European political history. He is known to have steadfastly espoused republican views. ${ }^{54}$ As a young man he was attracted to the ideas of the literary critic Wolfgang Menzel, including both an 1820 s version of political liberalism and a view of the arts as a political symbol for Germanspeaking people. 55 "Menzel's cultural nationalism circa 1828 underwent little change in Schumann, whose nationalism, although pronounced, never evolved into the more aggressive and modern form he would encounter in Dresden in the 1840s. The narrow realm of aesthetics as politics (creation of a like-minded public) remained Schumann's arena." 56 This proclivity is not surprising: belonging, as he did, to the minority of humanity whose existence serves to balance the majority's instinct for physical aggression, it was natural for him to seek to provide the intellectual and spiritual forces needed to engender change in society. ${ }^{57}$

In the early 1850s, though armed conflict had ended, citizens of Germanspeaking principalities and their assemblies of representation were undergoing a period of reaction to the few small libertarian gains from the period of strife and loss of life. Creation of a united, as well as more democratic, German nation was an unfulfilled aim of the revolutionary period. ${ }^{58}$ During the next two decades, the libertarian spirit was to be kept alive, and patriotism inculcated, by means of cultural activities specifically aimed at creating pride in a common German cultural background. ${ }^{59}$ Schumann was employing the strategy of "edification through the medium of music" when in Düsseldorf, in the fall of 1851, he organized a private club devoted to the singing of early polyphony and another club for chamber music. ${ }^{60}$

In the mind of Schumann as composer and music critic, composition as a force for social change depended upon the synthesis of a set of current aesthetic

53Botstein, "History, Rhetoric, and the Self," 6, 24-25.

54Daverio, Herald of a "New Poetic Age," 421-22.

55Botstein, "History, Rhetoric, and the Self," 16-17.

56 Ibid., 19.

57See $\mathrm{n} .47$. The self-understanding that caused Schumann to avoid testing his mettle for armed conflict at the height of the revolutionary period, and instead to flee from personal danger, has predictably earned the disapprobation of his biographers. See Daverio, Herald of a "New Poetic Age." 421-25.

58 J. M. Roberts sums up the situation this way: "no new nation emerged from 1848 for none was ready to do so. The basic reason for this was that over most of Europe nationalism was for the masses still an abstraction; only a relatively few and well-educated, or at least half-educated, people cared much about it. Nations, it was to appear, would in future be made after independence, by government and education, rather than emerge fully-grown." The Penguin History of Europe (London: Penguin Books, 1997), 403.

59 Hermann Kinder and Werner Hilgemann, The Penguin Atlas of World History, vol. 2, trans. Ernest A. Menze (Harmondsworth, Middlesex: Penguin, 1978), 61.

60Daverio, Herald of a "New Poetic Age," 446. 
principles. Like Jean Paul Richter and Friedrich Schlegel, he believed that, in the procedures of classical instrumental music (counterpoint, fugue, variation form, and sonata form), musical ideas are developed with the logic in which philosophical discourse develops ideas. ${ }^{61}$ Botstein goes on to explain that, influenced by the philosopher F. H. Jacobi, Schumann became convinced that one of the aims of philosophy, an encounter with the true nature of life in the present, is dependent upon the ontological priority of emotion-emotion understood as referring to the immediate and more powerful reactions of what in the twentieth century came to be understood as the subconscious mind. Emotion, however, arises not from reading philosophical discourse but from experience with art, especially nonlinguistic art. The understanding was that, because nonlinguistic art necessarily inspires emotional and, therefore, more penetrating understanding of the real world of human existence, the making of music, and repeated encounters with musical art works (not excluding criticism), all have an advantage over the writing and reading of philosophy as ways of understanding the human situation. Therefore, the sufficiently educated listener (the cultivation of which was one of Schumann's goals as critic and composer) would, by synthesizing music's appeal to reason and its appeal to the emotions, experience transformative encounters with "truth and the divine." 62 Like many present-day writers of music criticism who ponder the question of musical meaning, Schumann considered the meaning of a musical work to be a subjective construct of the mind of each individual, created and recreated with every listening to, and new critical commentary on, the work. ${ }^{63}$

Another of Friedrich Schlegel's influential theories was that music derives its rhetoric-like treatment of ideas from its historical role as the companion to epic poetry. As compared to past ages, said Schlegel, when poetry and music together recounted myth, legend, folk tale, and history, in his own time the remembrance function of epic poetry fell to music alone, which was expected to combine with that function the modern, descriptive and explanatory capabilities of the novel. ${ }^{64}$

There is a resonance between Schlegel's theory that music is genetically epic and Schumann's interest in music that is referential to the past. Daverio suggests that many of Schumann's late instrumental works are "essentially narrative" because they contain webs of motivic cross-references that by their

$61 \mathrm{Ibid}, 89$; Botstein, "History, Rhetoric, and Self," 26-28. Other applications of Friedrich Schlegel's critical thinking to Schumann's music are summarized by Erika Reiman in a review of John Daverio's Nineteenth-Century Music and the German Romantic Ideology (New York: Schirmer Books, 1993), in Journal of Musicological Research 16 (1997): 223-29.

62Botstein, "History, Rhetoric, and Self," 24.

63Plantinga, Schumann as Critic, 121.

64 Botstein, "History, Rhetoric, and Self," 26. It is noteworthy that the epic as literary analogue for music circumvents one of modern critics' principal objections to any alleged narrative capability for music - the difficulty of conceiving that music is capable of the necessary temporal-spatio separation between present time and place and represented time and place characteristic of narrative. If an instrumental work can, even temporarily, evoke the historical past-or seem to comment on historical musical procedure instead of merely being this musical procedure-music puts aside its mimetic qualities, removes itself from the present, and fulfills a requirement of narrative as opposed to mere narratography. McClatchie, "Narrative Theory and Music," 8. 
very use make deliberate reference to the necessity of remembering the past. ${ }^{65}$ According to Botstein, another element that substantiates the notion that Schumann regarded the transmission and inculcation of the history and aspirations of a nation to be an important function of art was his life-long interest in painting, in particular, large-scale epic painting. Schumann reveled in the ability of the epic canvases of members of influential German schools to evoke expectations about the present and future by alluding to the past. ${ }^{66}$ Some of his contemporaries were quick to notice the "painterly dimension" of his music. ${ }^{67}$ Adolf Schering wrote:

As important as Schumann is in his lyric works, ... he is at his greatest in his epic works-not the effete religious epic but the modern, romantic one, which has found its proper form in the romance, ballade, legend, novella, novel, and Märchen. In his romances and ballades for one and more voices; in Das Paradies und die Peri, Der Rose Pilgerfahrt, Der Königstochter, in the dramaticized legends Manfred, Faust, and Genoveva ... We have recognized the present time in music history as the painterly epoch and Robert Schumann as its first epic composer. ${ }^{68}$

Schumann's interest in German legends and folk tales was surely also related to his desire to evoke the German past, with the added attraction of their psychological allegories and plots dependent upon magical transformation. ${ }^{69}$ Daverio refers to the "epic" Der Rose Pilgerfahrt as a "fairy-tale oratorio."70

Similarly, when Schumann wrote: "[t]hose whom [Hoplit and his party] take to be musicians of the future, ... I consider musicians of the present, and those whom they take as musicians of the past (Bach, Handel, Beethoven) seem to me the best musicians of the future," he was not striking a reactionary stance against the New German school so much as remaining consistent with his belief that for the sake of the future the cultural past has a salutary superiority over the present. ${ }^{71}$ For Schumann as composer in the present, "[a] work of music

65Daverio, Herald of a "New Poetic Age," 469.

66 Botstein, "History, Rhetoric, and Self," 38-39.

67 Ibid., 46 n. 104.

68 Adolf Schubring, "The Present Musical Epic and Robert Schumann's Position in Music History," trans. John Michael Cooper, in Schumann and His World, Todd, ed., 371; originally published as "Die gegenwärtige Musikepoche und Robert Schumann's Stellung in der Musikgeschichte," Neue Zeitschrift für Musik 54 (1861): 197-98, 205-6, 213-14.

69During Schumann's childhood, the philologists and folklorists Jacob and Wilhelm Grimm recorded and published the first German folk tales in the three volumes of Kinder- und Hausmärchen, 1812,1814 , and 1822. They also concerned themselves with authentic mythology, heroic songs, and sagas from the entire range of Germanic culture, thereby exerting an important influence upon German romanticism. Chamber's Encyclopadia, new rev. ed. (London: International Learning Systems, 1973), vol. 6, 605 .

70 Daverio, Herald of a "New Poetic Age." 469.

71 Ibid., 478-79. Similarly, Larry Todd argues that where Schumann's music pays homage to the stile antico (as in the fourth movement of the Third Symphony) or to the style of Bach (as in the Fugues on $\mathrm{BACH}$ ), he does not display mere imitation, but the practice of his stated belief that the future of music is to be achieved by demonstrating exalted rereadings of music of the past; $R$. Larry Todd, "On Quotation in Schumann's Music," in Schumann and His World, 97-100, 109. 
was therefore a narrative suffused with a nearly irrational link to the imagined past, replete with a contemporary collective aura and significance."72

This is the social and ideological context in which, toward the close of 1850 , Schumann wrote his Third Symphony, purportedly inspired by the sight of a cultural monument, Cologne's magnificent cathedral, while on a journey along the Rhine River. ${ }^{73} \mathrm{He}$ had recently taken on the very public task of municipal music director in Düsseldorf. Schumann knew that a large part of an audience considered music to be pleasant entertainment but not a vehicle for serious ideas. Strategically, his stated modus operandi in composing the symphony was that "popular elements should prevail"; the work was indeed a popular success from the moment of its first performance in February, 1851.74 If, consistent with the ideas and social circumstances described above, it was his hope to give broadly cultured German-speaking listeners an edifying encounter with the past-their cultural heritage-so that from repeated listenings they would gain a new perspective on the present-potentially transformed into proud citizens of a future, united German nation-how might he have intended the first movement of the Third Symphony to do this?

In an approach toward the question of meaning in Schumann's music, Anthony Newcomb has argued that nineteenth-century instrumental music achieves narratographical effects when the musical work problematizes or otherwise defamiliarizes conventions of classical compositional procedures. ${ }^{75} \mathrm{He}$ draws particular attention to reversals of technical musical functions in Schumann's works: for instance, an ostensible rondo in which "the harmonic and metrical construction of the so-called episodes is considerably more stable than that of the refrain."76 Precisely this sort of "irrational" approach is, to Botstein, Schumann's method of reinterpreting the past. Schumann's aesthetic of music was

... a synthesis of reason and fantasy. The rational (the explanatory function) was contained in formal procedures-in the case of Schumann's music, in sonata form, variation form, and counterpoint. The phantasmagoric emerged from the free interplay of fantasy in harmony, melody, and asymmetrical rhythm, which worked in contrast to the expectations of form. As if to parallel the distinction between the unconscious and the conscious, the epic and therefore each piece of music - in the spirit of Jean Paul's twins-had two levels of compositional intentionality in the text. ${ }^{77}$

72 Botstein, "History, Rhetoric, and Self," 26.

73 Wilhelm Joseph von Wasielewski, Robert Schumann: Eine Biographie, enlarged ed. (Leipzig: Breitkopf \& Härtel, 1906), 455; cited in Daverio, Herald of a "New Poetic Age," 442.

74 Ibid., 456; cited in Daverio, Herald of a "New Poetic Age," 465.

75 Anthony Newcomb, "Schumann and Late Eighteenth-Century Narrative Strategies," 19th Century Music 11 (1987): 164-74. Compare also Lawrence Kramer's summary statement at the end of a paragraph on narratography: " $[t]$ o use Nattiez's terms, music compels us to the narratographic metaphor precisely when it seems to be undercutting its own foundations." Classical Music and Postmodern Knowledge, 101-2.

76 Newcomb, “ Schumann and Late Eighteenth-Century Narrative Strategies," 172.

77 Botstein, "History, Rhetoric, and Self," 27. A detailed study of Schumann's aesthetics in relation to his own music is Erika Lynne Reiman's "Schumann's Piano Cycles and the Novels of Jean Paul: Analogues in Discursive Strategy" (Ph.D. diss., University of Toronto, 1999). 
The foregoing accounts of Schumann's aesthetic ideology and Newcomb's insights on narratographical method in Schumann's music have bearing on Krebs's analysis of metrical process in the first movement of Schumann's Third Symphony that, in turn, suggests a possible interpretation of meaning in the music. The analysis of the movement in Fantasy Pieces emphasizes the logical processes undergone by each type of metrical dissonance within the movement; it notes where metrical dissonances are structural markers for the conventional phases of sonata form. But by the late eighteenth century, Beethoven was already intent upon reconfiguring stable and unstable elements in ways that would defamiliarize sonata procedure. ${ }^{78}$ If the succession of changes in metrical state in the Schumann movement is narratographical, it must be because, in interaction with other musical parametres, it constituted for Schumann's contemporary performers and audiences a problematization of sonata procedure.

The manner in which the symphony opens gives reason to suspect that the first performers and their audience would have sensed that they both did, and did not, understand the orchestra's first utterances. They would have sensed the topic of the theme: its bold triadic leaps (in the key of E-flat for the sake of the accompanying horns) would have denoted the horn call of the old-fashioned hunt, and conveyed connotations that were both picturesque-the associated natural landscape - and a source of collective pride-a social activity associated with manly heroism, and, by extension, pride in the homeland. Equally understood, the heroic hunting motif, although still current as a signifier, was "an imaginary signified plucked from the culture of several centuries previous," and chosen to refer listeners to their collective, and perhaps, subconscious, memories of their cultural past. ${ }^{79}$ Of all possible topics with reference to the past, this one is suitably lofty and sufficiently grandiose to begin an "epic" symphony.

Strangely, though, Schumann's heroic theme is arranged so as to sound like neither an introductory gesture nor a thematic exposition. One factor sending the "wrong" signal is textural: at the initial downbeat, winds, timpani, and strings plunge precipitously into an accompanimental fanfare-while the heroic

780n Beethoven's tendency to reconfigure tonal and melodic states in his early sonata-form movements for piano, see Carl Dahlhaus, Ludwig van Beethoven: Approaches to His Music, trans. Mary Whittal (Oxford: Clarendon, 1991), 96-105. The case of an apparent second subject that is equally a continuation of the transition process is discussed on pp. 102-5, where Dahlhaus concludes: “... the redistribution of attributes is governed by an aesthetic concept that was known to baroque poetic theory-which experienced a revival of interest among the early romantics-as 'beautiful confusion' ... Sometimes Beethoven lets us feel that he was a contemporary of Jean Paul, but the relationship registers as no more than the occasional flash of lightning, and it would be a mistake to think of it as an established factor in terms of the history of ideas."

79Raymond Monelle, "An Historical Approach to Musical Topics" (Musical Intersections, Society for Music Theory Session, Toronto, November 2000). According to Monelle, in eighteenth- and nineteenth-century instrumental music, the "heroic" quality of the hunt topic could only have been a reference to a bygone age because recreational hunting had by then turned into organized slaughter with minimal risk to human participants. Beethoven could unconsciously adopt the horn call to symbolize military heroism in his Symphony No. 3 in E-flat only because Europeans around 1800 still knew hunting as a training ground for the military. See also Raymond Monelle, The Sense of Music: Semiotic Essays (Princeton: Princeton University Press, 2000), 38-40. 
theme, unannounced, is played by first violins and flutes-as if, chronologically, the moment were one calling for a sudden, climactic tutti (a significant juncture in a concerto movement, or the onset of a rondo reprise), rather than the opening of a symphony.

The other factor is metrical dissonance, described very clearly in Fantasy Pieces:

[T] he first movement ... will appear to begin with two juxtaposed metrical consonances (example 2.5) [example 3 here]. The first six measures apparently establish the consonance $12 / 4 / 2(1=8$ th $) ..$. More sophisticated listeners ... might also observe that the initial 4-layer conflicts with the conductor's beats, which would, at the movement's quick tempo, express the metrical 6-layer. They would, furthermore, perceive $\mathrm{m}$. 7 as the point of resolution of this conflict. Even without watching the conductor, I believe, the attentive listener would gain from $\mathrm{m} .7$ an impression of resolution, or at least relaxation, as a result of the broadening from a governing 4-layer to a 6-1ayer. ${ }^{80}$


Example 3. Fantasy Pieces, example 2.5: a visual explanation of changing audible metrical states in bars 1-9 of Schumann's Symphony No. 3, first movement. From Fantasy Pieces: Metrical Dissonance in the Music of Robert Schumann, by Harold Krebs. (C) 1999 by Harold Krebs and published by Oxford University Press, Inc.

As this analysis goes on to observe, during the opening six measures, performers and listeners will have, at the very least, a subliminal sense of metrical instability. As originally defined in Fantasy Pieces, subliminal dissonance must begin from "indirect dissonance," that is, with a consonant state followed by another metrical state that is consonant within itself but dissonant with the preceding metrical state (which, although now ended, is mentally retained for a short time). If the new metrical state is continued beyond the point of conscious memory of the preceding one, the performer's and listener's sense of metrical conflict may yet survive subliminally, particularly if, as in the typical situation, the performer remains aware of the original metrical state 
from the notation, and conveys this veiled metrical layer through body language (such as the conducting gesture). ${ }^{81}$ Measures 1-6 of the symphony, however, although giving the impression of containing subliminal dissonance, logically do not begin as a case of indirect dissonance. This exception, instead of casting doubt on the original definition of subliminal dissonance, confirms the syntactical irregularity of the opening metrical state. Because the metrical consonance that should have preceded it is absent, the listener senses at the start a problematization of the possible ordering of musical events-solved only by concluding that one has been intentionally plunged in medias res. ${ }^{82}$ The same electrifying technique that native German speakers would have experienced in the novels of Jean Paul confronted them in the Düsseldorf concert hall. Therefore, while the mimesis is to heroism of a past age, the narratographical technique of beginning at what is surely not the beginning transposes the reference to heroism to a future, transformed state. Through the irrationalization of musical time, historical time and future time are subjected to fantastical simultaneity. Through a metrical technique - alteration of the subliminally triple-metre opening measures by means of the increased urgency and forward drive of duple metre- the dynamic nature of the future state is conveyed.

The next stage of the movement's sonata form reverses the process of gradually increasing metrical instability found in a paradigmatic transition passage:

The transition (bars 57-94), largely modeled on the first theme, continues to alternate $12 / 6 / 2$ and 12/4/2 ... [In contrast the final measures of the transition (bars 83-94) are virtually consonant. ${ }^{83}$

Together with its shift to a weakly established new key, G, the transition systematically undermines the emergence of the lyrical theme. ${ }^{84}$ Indeed, the lyrical theme is merely a four-bar phrase given two statements, the first a harmonically incomplete statement in $G$, the second modulating from $G$ to B-flat. In the latter key, it is interrupted by thirteen measures of material from the heroic theme (or that theme's passage work) with its characteristic full texture and subliminal metrical disturbances. The pattern consisting of two four-bar statements of the lyrical theme modulating from $\mathrm{G}$ to B-flat followed by a B-flat-major reprise of the heroic theme is immediately repeated, this time climaxing in metrical conflict announced in its strongest terms yet. Therefore, despite a recognizable configuration of events-modulation to $G$ in prepara-

81 Ibid., 46-47.

82 In an article about musical time, Jonathan Kramer writes: "we understand when a gesture seems to be misplaced ... and we await the consequences of this misplacement." Jonathan Kramer, "Postmodem Concepts of Musical Time," Indiana Theory Review 17, no. 2 (1996): 30.

83 Krebs, Fantasy Pieces, 239-40.

84 The transition's first twenty measures (bars 57-76) preserve the original, strong, mid-level metric conflict and E-flat tonicity; the succeeding six-bar hypermeasure of three two-bar units-which in its original presentation within the E-flat-major group was equally unstable in its harmony-now, as part of the transition, sidles its way to $V$ of $G$ in harmonically sequential pairs of measures. This is where forward propulsion is replaced by stasis. The dominant of $G$ is now subtly affirmed in three four-bar hypermeasures devoid of metrical conflict-the first two iterating a recessive melodic contour, and the third, diminuendo, prolonging $\mathrm{V}$ of $\mathrm{G}$ with its own tonic. 
tion for a lyrical theme-what was doubtless the "contrasting theme" (and apparently the contrasting key) have appeared prior to the climactic arrival of the definitively established opposing key, B-flat major. The "recognizable events" were instead a "disguise" by which V/III and III were momentarily made stable in support of a brief lyrical melody. Just as intriguing, the theme that bears the secondary tonic in which the exposition ultimately remains is the heroic, opening theme, still wearing its metrical dissonance and the texture of a climactic reprise, unconcerned with projecting a new character for its new role. Schumann may have intended this relational disarray to serve both as a set of witticisms and as a set of deliberately irrational states or "disguises" in preparation for later "unmaskings," the strategy that Jean Paul used in his novels:

The jest revealed the irrationality of daily life and the individual's resentment of that irrationality. Disguised similarities were unmasked. The rational and unexceptional, therefore, masked the grotesque and bizarre. Likewise, the eccentric, the ironic, and the unusual overtly camouflaged the reasonable, the ordinary, and the decorous. ${ }^{85}$

In the development section, as described in Fantasy Pieces, the motivic implications of the movement's displacement dissonance are gradually and rationally worked out. In contrast, the heroic theme, in whatever key is current, but unchanging in its metrical dissonance and in its costuming as a pseudo-climactic tutti, periodically interrupts the development procedure.

At the actual climax of the development section, the temporal stance of the heroic theme shifts yet further toward the past (example 4).

[The retransition] begins with a magical moment; against a static background of tremolos and sustained notes, the horns portentously present a metrically consonant version of the opening theme (bars 367-70). From this form, there emerges the usual subliminally dissonant "duple" version of the theme, which now sounds like a distortion of the consonant form (bars 371-73). $]^{86}$

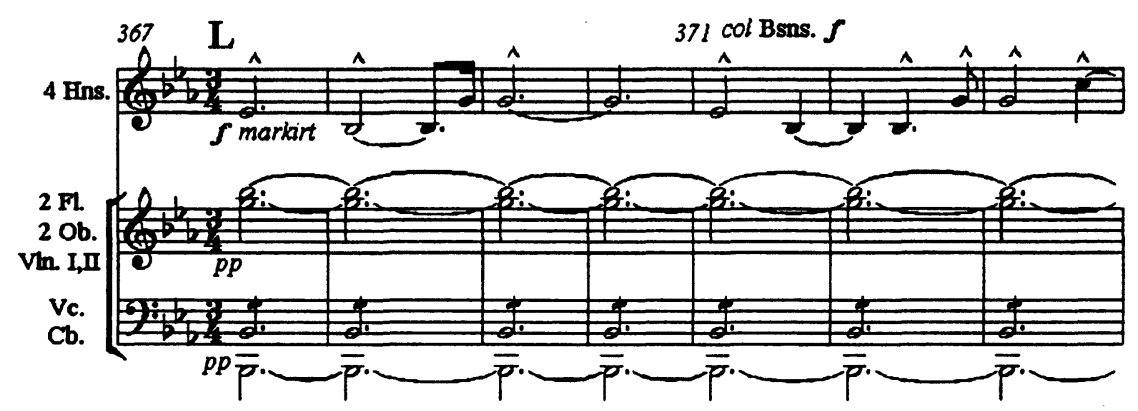

Example 4. Climax of the development section of Schumann's Symphony No. 3, first movement (present author's score reduction), beginning with the generating form of the heroic theme in bars $367-70$. 
Occurring in bars $367-70$ in its originally suppressed, but narratographically prior, generating form, the heroic theme now reveals the narrative past that precedes even the opening of the movement. As when in a narrative that began in medias res a climactic disclosure of originally suppressed events takes one by surprise, in this musical work the moment of revelation of the conceptually prior metrical state of the heroic theme is a turning point whose climactic impact would not have been possible with linear presentation. ${ }^{87}$ More importantly, this moment is unambiguous confirmation of the role of the historical past in the movement as model for the present and future. Explicit comparison of the heroic theme's underlying triple metre with the urgency and forward drive of its adopted duple metre confirms that the theme is not meant to evoke the glorious past for its own sake but for the sake of the living present as it continues into the imagined future.

The logic with which the recapitulation concludes the movement, logic evident in metrical process as well as in harmonic process, is consistent with Schumann's alleged belief in the comparability of musical process to the logic of philosophical discourse.

The recapitulation is much like the exposition in terms of metrical structure. In terms of hypermeter, however, it differs significantly; several passages of the exposition that involved hypermetrical dissonance are not recapitulated ... so that the recapitulation contains less hypermetrical disturbance than the exposition. The recapitulation thus paves the way for the coda, which, not surprisingly, performs a resolving function. ${ }^{88}$

It is of music-theoretical significance that a logical process exists in the overall rhythmic domain as well as in the pitch domain. Nevertheless, as Schumann understood meaning in listeners' minds to result from the composer's use of both the rational and irrational, the overall, rational course of metrical states alone is inadequate for any intended extramusical meaning. Schumann would more likely have hoped that, in the spirit of picturing one of Jean Paul's characters participating in the intrigue of a masked ball, some listeners, upon repeated hearings of the symphony's first movement, would come to realize that the apparently ordinary (sonata form) disguised the extraordinary, and the seemingly bizarre (the first theme's abrupt entry and metrical incongruity) masked a familiar topic. In the symphony's first movement, recognition of sonata procedure could evoke the past, convey (as it did a century before) the logic of written discourse, and, where used irrationally, suggest fantastical reversals of the ordinary. Headed by the heroic theme in its grandiose orchestration, the symphony might, like a sung epic, convey images of the past but, being nonverbal, stir up subconscious sentiments evoked by these images, possibly including pride in heroism for the sake of a homeland. Reversal of a formal procedure, presenting the first theme on the initial downbeat without introduction, in a metrically deviant and texturally overblown guise, could be

87Daverio notes something similar in the Symphony No. 1, first movement, where the reprise of the motto at the climax of the development section is "an overcharged gesture whose threat to the balance of the movement exposes the fiction that music must proceed as a seamless, logical discourse." Herald of a "New Poetic Age," 232.

$88 \mathrm{Krebs}$, Fantasy Pieces, 242. 
meant to make the listener sense that the generic and topical allusions to the past, rather than being purely antiquarian, are to be understood in relation to the present and future. It is possible that Schumann intended the symphony to be a manifesto of the cultural values (collective pride in a united Germany) that could help shape a nation. It would be consistent with Schumann's belief in the greater rhetorical efficacy of musical discourse as compared to philosophical discourse that any such idea would occur only at an unconscious level, that is, would be emotional rather than rational.

Achievement of an extramusical intention of this kind would have required repeated listenings, in a philosophical climate that continued to regard instrumental music as capable of conveying meaning. Unfortunately for this potential, in 1854, the same year that Schumann was hospitalized, Eduard Hanslick published his celebrated treatise on musical aesthetics that would include Schumann's music with that of Mendelssohn and Brahms in an argument for instrumental music as an autonomous art. Indicative of the aesthetic climate around 1860, five years after the composer's death, the self-described Schumannianer Adolf Schubring (a judge by profession) found it necessary to argue for the content of Schumann's music:

\begin{abstract}
Why Schumann's genius in all its greatness has been recognized by so few until now lies in his ideally realistic truthfulness, in the fresh colors of his images, in the novelty of his ideas ... in the new content, which for most of his contemporaries remained a closed book in Schumann's works. Of course, in a new work everyone reads only what he has already experienced as true, or whatever else has slumbered unconsciously within, waiting only to be stirred. ${ }^{89}$
\end{abstract}

If the foregoing construct of meaning in the first movement of Schumann's Third Symphony, for all its contingency and subjectivity, is a credible example of the kind of content Schubring had in mind, it is indebted to knowledge of two types. One is knowledge from pre-existing studies concerning nineteenthcentury aesthetics, European social and cultural history, and Schumann's biography. The other is knowledge from a pre-existing study on compositional techniques, Harald Krebs's monograph on metrical dissonance in Schumann's music.

In part two of my dialogue with Fantasy Pieces I took issue with the metaphor "metrical narrative": the word "narrative" ("telling of a story") promises to say how awareness of metrical techniques creates meaning, but ends by being an alternative term for "structure." I also took issue with the pervasive manner in which Fantasy Pieces makes connections between the negative aspects of Robert Schumann's personal life-particularly his mental illness-and the composer's use of metrical dissonance, on the grounds that it does a disservice to Schumann's creative genius. A natural conclusion is that it is no simple matter for one scholar, even in a substantial, detailed, and 
elegantly written study, to do justice to both theoretical and hermeneutical questions about music.

In part three of this essay, I demonstrated an approach to the question of how metrical dissonance can create meaning in music, building upon an analysis from Fantasy Pieces. I drew two conclusions. First, that as a basis for interpreting Schumann's compositions in large, public genres such as the symphony, one does well to employ not only knowledge of the composer's personal circumstances, but also knowledge of his political beliefs and aesthetic goals. Second, that metrical dissonance can do more than create a progression of moods or affects within an instrumental movement. When metrical dissonance plays a role in disguising the elements of a musical topic, particularly in combination with defamiliarizing formal relationships of an established musical form, it imbues the musical topic with a layer of meaning that would not otherwise have been present.

The first part of this essay drew attention to the activities of theory and analysis as they are performed in Fantasy Pieces. First, the Florestan-Eusebius dialogues contribute to the cogency of the book's theoretical formulations and analytical arguments; therefore, I suggest that the explanatory value of a mode of discourse that anticipates and answers possible objections of a reader cannot be overestimated. Second, the book's protagonists model how to read musictheoretical discourse. It must be digested in relatively small amounts, with frequent breaks for reflection and for mental activity of the sort needed to integrate concepts into one's own frames of reference. Music-analytical discourse presumes that one possesses the musical work or works under consideration in one's aural memory. In short, "reading" music theory is not a purely linguistic activity, but a musical activity.

It is the job of a theorist to provide tools with which scholars of music may draw distinctions between, and make reasonably unambiguous statements about, musical states. Although not the only tools of the historian, teacher, and scholar, it is undeniable that, when wisely used, theories and analytic methods have enabled the activities of style analysis, pedagogy, and criticism. The demonstrated efficacy of contributions such as Harald Krebs's Fantasy Pieces suggests that as music-theoretical concepts undergo further refinement in the literature they will continue to make valuable new contributions to musical scholarship. 